\title{
Dimensions Of Indian Urban Centers: Some Policy Implications
}

\author{
Debnath MOOKHERJEE*
}

In view of the phenomenal rise of India's urban population during the postindependence period, a great deal of research interest has been focused on urbanization-urban process, growth strategy, planning and policy formulation. Few other fields in the social sciences may be considered to be more richly deserving of this interest, for although the 79 millions of urban dwellers of India in 1961 comprised only 18 percent of her total population, she experienced nearly eighty percent growth in urban population over the period of 1941-61, and the current estimates indicate that even on a conservative basis the urban population of the nation is likely to be of the order of 152 million in 1981 (Chandrasekhara, et al., 1971:78). The most disturbing aspect of this urban growth is that, with their already inadequate or severly strained resources, and with all the "dirt, the squalor, the overcrowding, [and] the grinding poverty. .." the larger urban centers as a group have continued to increase at a much faster rate in comparison to other urban units. During the 1941-61 period the cities and town groups with population of 100,000 and over have grown nearly 150 percent, adding a total of twenty-one million additional people. ${ }^{1}$ This disproportionate urban growth rate, along with an excessive concentration of industries in the larger urban centers, has led the Planning Commission in the recent years to set their objectives in favor of a "decongestion or dispersal of population" from the largest metropolitan centers, and exploration of smaller towns with potentials for development (Government of India, Planning Commission, 1970:398).

However, this deliberate policy of deconcentration of industry from the major urban agglomerations and of locating the new industries in medium and smaller towns and villages, in order to create alternate forms of urban growth-points, ${ }^{2}$ have raised some serious sociopolitical and economic issues. Those concerned are divided in their opinion as to the most appropriate ways by which to ameliorate the complex problems of cities and at the same time to maintain an equilibrium of development between the urban and rural areas. ${ }^{3}$

Proponents of the "centralization policy" base their arguments primarily on economic and technological grounds. According to them, although continued centralization of economic activities and population in larger cities might initially contribute to regional disparity, eventually, through the so-called "trickle-down" process, an orderly and harmonious developmental scale leading to a progressive "integration of space-economy" would come about. Sustained growth in some of

*Professor of Geography and Director of Urban and Regional Planning Program, Western Washington State College, Bellingham, Washington 98225, USA. 
the metropolitan cities due to their environmental advantages, may "reinforce the cycle of growth," and hence the long range national developmental interests probably would be better served if the present pattern of growth were allowed to continue in such urban centers. ${ }^{4}$ This appeared to be the prevailing belief that guided the planning authorities during early stages of the planning period.

In contradistinction to the above, those believing in a "dispersed development" policy, advocate an induced change in the present system with the aim of mitigating the regional and urban-rural imbalances in development, as well as many of the current social, economic and political problems of the largest cities. As steps towards this goal, they propose a policy of discouraging further growth by initiating measures to decentralize the industry and to encourage growth in the smaller urban and rural settlements. Also, creation of new towns along with satellites to share the burdens of the ever-expanding metropolitan areas is considered as a major strategy. They contend that though India has progressed through industrialization in the technical sense, the fact remains that the benefits which have accrued from such developments are concentrated primarily in the "elites" among the larger cities, and hence, in shaping the current developmental pattern into a "balanced" state, every national effort must be directed toward fostering a "social industrialization" ${ }_{5}$ policy. Certain measures-as for example, issuance of licenses to control and direct industrial location, and establishment of industrial estates-have already been undertaken by the government. However, such measures have shown only limited success, as during the period of 1952-64, when about sixty-five percent of the licenses went to cities of over 100,000 population (Roth, 1970:392). It is increasingly felt that attempts to limit the urban growth on a piece-meal basis is not likely to succeed, and therefore, one integrated and comprehensive urbanization policy by recognizing the interplay of the inherent environmental forces at the local and regional levels is urged.

An extensive body of contemporary literature on urban affairs shows that while scholars from various social science disciplines have studied cities from the points of view of their own fields of interest and have provided valuable information on diverse urban problems useful in the conception of broad objectives of planning, there appears to be a need for further research on urban centers from an ecological perspective, especially in devising an effective policy toward directing urban growth. There is a growing realization among scholars that size alone should not be the sole criterion used to justify the decentralizers' cause. The idea of choosing small centers because of their "simplistic-size-of-place criteria" or due to their slower growth (the "worst-first policy"), for locating industries toward balancing the nation's urban growth has to be considered carefully as there is yet no convincing research which shows that such centers are capable of accommodating or promoting growth. Systematic studies in understanding the forces leading to the making of urban structures and the interrelationships among various physical and non-physical factors in a given urban environment are to be considered toward revealing the total profile of the cities and towns (Manickam and Misra, 1968:601). Do the socio-economic characteristics of the urban places of India vary with size and growth rates? How is their urban space utilized in relation to the occupational structure of the population? What similarities or di- 
versities are observed in the structural patterns of the smaller or slow growing urban centers as compared to their larger or faster growing counterparts? Would they reflect any locational significance? These are some of the questions that need to be asked in developing an effective urbanization policy. Some research has been carried out which sheds light on aspects of the above. However, the need to identify the structural characteristics of urban centers from the perspectives of location, size, and growth pattern has not received adequate consideration in systematic research. Complete answers to the questions raised above is beyond the scope of the present paper but we propose to take an exploratory step toward revealing and comparing the structural patterns of selected towns and cities of India in order to provide some insights for social scientists and urban planners concerned with the formulation of an appropriate policy.

\section{Research Design}

The previous ecological studies of Indian urban places were particularly confined to larger cities with emphasis on certain socioeconomic variables. ${ }^{6}$ However, primarily due to a paucity of data, research studies encompassing the smaller centers and taking some physical (such as land use), as well as socioeconomic factors under consideration have received rather limited attention. Consequently, in the assessment of urban environments the relationship between the socioeconomic and land use factors has, to a large extent, been a matter of conjecture. ${ }^{7}$ For the present study, the selection of urban places and variables has been limited by the availability of published data, and as such a set of seventeen demographic, economic and land use variables were selected for the analysis of forty-four urban places of 50,000 population and over (Table 1). In order to make an interpretative assessment of the urban dimensions in relation to size, growth and location, the cities were grouped according to (A) population size-100,000 and over, and between 50,000 and 100,000; (B) locational characteristics-distance from a "million" city-forty miles and below, and over forty miles; and (C) growth characteristics - growth rate of twenty-five percent and over, and below twenty-five percent, for the 1951-61 period. ${ }^{8}$

Principal component analysis with normal varimax rotation was considered to be most appropriate in examining the structural characteristics of cities for each of the above groups. ${ }^{9}$ Because of the non-normal distribution of data, Spearman's Rank Order correlation, instead of the more usual Pearson $r$ was employed. ${ }^{10}$

\section{Emerging Patterns}

The simple correlation among the variables chosen for the three groups of cities indicate that both in the groups of cities nearer to the "million" cities and those with a lower growth rate, the total labor force shows a high positive correlation with workers in the secondary sectors and with total, developed, and residential density. In view of the industrial concentration and over-all congestion in the larger centers, this pattern would also be expected in the larger cities. However, no clear pattern seems to emerge from the correlations, as, contrary to the expectations, labor force and workers in secondary activities show high positive correlation in the smaller groups of cities, even though a positive association 
TABLE 1

\section{THE VARIABLES USED IN COMPONENT ANALYSIS FOR SELECTED INDIAN CITIES AND TOWNS}

\begin{tabular}{|c|c|c|}
\hline Names & & Explanation \\
\hline 1. Population & POP & Total population, 1961 \\
\hline 2. Sex ratio & $\mathrm{SR}$ & Females per 1000 males \\
\hline 3. Literacy & LIT & Male literates per 1000 total population \\
\hline 4. Labor Force & $\mathbf{L F}$ & $\begin{array}{l}\text { Male workers in primary, secondary, and tertiary sectors as per- } \\
\text { centage of total population. }\end{array}$ \\
\hline 5. Primary & PR & $\begin{array}{l}\text { Male workers as cultivators, agricultural laborers; in mining, } \\
\text { quarrying, livestock, forestry, fishing, hunting and plantations, } \\
\text { orchards and allied activities as percentage of total population. }\end{array}$ \\
\hline 6. Secondary & $\mathrm{SEC}$ & $\begin{array}{l}\text { Male workers in household, manufacturing and construction as } \\
\text { percentage of total population. }\end{array}$ \\
\hline 7. Tertiary & TER & $\begin{array}{l}\text { Male workers in trade and commerce, transport, storage and } \\
\text { communication and other services as percentage of total popula- } \\
\text { tion. }\end{array}$ \\
\hline 8. Density & $\mathrm{DEN}$ & Population divided by total urban area. \\
\hline $\begin{array}{l}\text { 9. Developed } \\
\text { area }\end{array}$ & DA & $\begin{array}{l}\text { Land in urban use (residential, commercial, etc.) as per } \\
\text { of total area. }\end{array}$ \\
\hline 10. Residential & RES & Residential area as percentage of total area. \\
\hline 1. Commercial & $\mathrm{COM}$ & Commercial area as percentage of total area. \\
\hline 12. Industrial & IND & Industrial area as percentage of total area. \\
\hline 13. Public & PUB & Public and semi-public areas as percentage of total area. \\
\hline $\begin{array}{l}\text { 14. Parks \& } \\
\text { Playgrounds }\end{array}$ & PRK & rcentage of total area. \\
\hline $\begin{array}{l}\text { 5. Roads and } \\
\text { Streets }\end{array}$ & RDS & d streets as percentage of total area. \\
\hline $\begin{array}{l}\text { 16. Developed } \\
\text { density }\end{array}$ & $\mathrm{DD}$ & Total population divided by developed area. \\
\hline $\begin{array}{l}\text { 17. Residential } \\
\text { density }\end{array}$ & $2 \mathrm{D}$ & Tot: \\
\hline \multicolumn{3}{|c|}{$\begin{array}{l}\text { Variables 1-7, Census of India 1961, "Paper No. } 1 \text { of 1962," New Delhi, } 1962 . \\
\text { (All data refer to 1961.) } \\
\text { Variables 8-17, Town and Country Planning Organization, "Land Use Pattern of } \\
\text { India's Cities and Towns," Urban and Rural Planning Thought, October } \\
\text { 1968, Appendix III. (About eighty percent of the data refers to 1961-1963 } \\
\text { period.) }\end{array}$} \\
\hline
\end{tabular}

between labor force and urban developed and residential land density is noted in cities of over 100,000 population.

In the component analysis the dimensions of each of the six groups account for at least seventy percent of the total variance. The first component in the three groups mentioned above, may clearly be termed as industrial-congestion (as a distinct cluster of certain economic and land use variables appear with high factor loadings). ${ }^{11}$ The remainder of the dimensions seem to portray one or the other of the major attributes which may generally be named as land use, indus- 
trial (secondary, industrial area), commercial (tertiary, literacy), congestion (various densities), or mixes thereof. However, for the purpose of the present paper we propose to discuss the first component for each group which accounts for the highest variation. ${ }^{12}$ The remaining components are presented in the Appendix.

In spite of differences in loadings, the close approximation of the first dimensions in each of the larger, and slow growing group, and in the cities at the closer proximity to a "million" city is apparent from Table 2 . In each case the dimension indicates a polarization between the primary and secondary sectors with the predominantly secondary employment-oriented or industrial cities with a higher total, residential and developed land density, a larger industrial area and possibly a well developed network of roads and streets. Evidently, industrial polarization is present in the first dimensions of the other groups of cities as well; although they do not portray the concomitants of industrialization (as the three types of densities, and a large industrial area) as consistently as their counterparts. In brief, then, it appears that industrial congestion is the basic trait that stands out in the first dimensions in each of the three groups identified as Industrial-Congestion Prone (ICP) groups. The factor scores tend to conform to the occupational classification of the cities in the Census Reports (Census 1961, 1970: Maps 54-55) and generally support these components.

\section{Conclusion}

The implication of the above findings in the context of industrial decentralization lies in the cautionary note it sounds against any hasty generalization and

TABLE 2

COMPONENT-I: SELECTED CITIES AND TOWNS

\begin{tabular}{|c|c|c|c|c|c|c|c|c|c|c|c|}
\hline \multicolumn{4}{|c|}{ Size } & \multicolumn{4}{|c|}{ Growth } & \multicolumn{4}{|c|}{ Location } \\
\hline \multicolumn{2}{|c|}{$\begin{array}{c}100,000 \text { and } \\
\text { over }\end{array}$} & \multicolumn{2}{|c|}{$\begin{array}{l}50,000 \text { to } \\
100,000\end{array}$} & \multicolumn{2}{|c|}{$\begin{array}{l}25 \text { percent } \\
\text { and over }\end{array}$} & \multicolumn{2}{|c|}{$\begin{array}{l}\text { Below } 25 \\
\text { percent }\end{array}$} & \multicolumn{2}{|c|}{$\begin{array}{l}\text { Over } 40 \\
\text { miles }\end{array}$} & \multicolumn{2}{|c|}{$\begin{array}{l}40 \text { miles } \\
\text { and below }\end{array}$} \\
\hline DEN & .89 & TER & .83 & $\mathrm{LF}$ & .89 & PRI & .78 & SEC & .78 & $\mathrm{DD}$ & .87 \\
\hline DD & .87 & PRI & .71 & RDS & .52 & TER & .56 & POP & .75 & SEC & .83 \\
\hline RD & .87 & & & DEN & .52 & & & RDS & .62 & IND & .79 \\
\hline LF & .78 & & & & & & & IND & .52 & $\mathrm{LF}$ & .77 \\
\hline SEC & .62 & & & & & & & & & $\mathrm{DEN}$ & .72 \\
\hline $\mathrm{RDS}$ & .60 & & & & & & & & & $\mathrm{RD}$ & .65 \\
\hline IND & .52 & & & & & & & & & $\mathrm{RDS}$ & .63 \\
\hline PRI & -.76 & $\mathrm{DD}$ & -.78 & $\mathrm{SR}$ & -.74 & IND & -.91 & PRI & -.63 & PRI & -.89 \\
\hline SR & -.62 & SEC & -.61 & PRI & -.61 & SEC & -.90 & & & SR & -.83 \\
\hline & & IND & -.51 & & & DEN & -.85 & & & & \\
\hline & & & & & & $\mathrm{DD}$ & -.83 & & & & \\
\hline & & & & & & RDS & -.70 & & & & \\
\hline & & & & & & RD & -.68 & & & & \\
\hline & & & & & & $\mathrm{LF}$ & -.53 & & & & \\
\hline
\end{tabular}

Percent Variance:

31

27

26

35

25

37 
policy formulation. Similarity of the industrial congestion dimensions in the three groups categorized according to the three criteria of size, growth, and location suggest that this factor may not necessarily be limited to, or symptomatic of, only urban centers of over certain size. Indeed, in this study, some of the smaller cities that belong in either of the other two ICP groups show high values in the dimensions of industrial congestion, thus suggesting that any decision regarding the location of industries in these cities because of their smaller size should be made only after careful assessment and evaluation of other locational-environmental factors such as resources, market, etc. If, for instance, with size as the determining factor, location of certain industrial undertakings is directed toward some smaller urban centers which show a dominant industrial congestion structure, the net effect of this would be not a solution, but a transplantation of the problems that plague the larger cities. So would be the case of selecting cities on the basis of locational or growth pattern as the sole criterion. On the other hand, the larger urban places at the other end of the scale in the ICP groups, those with predominantly primary or primary-tertiary employment oriented characteristics and apparent lack of congestion, should not be excluded from consideration for potential industrial sites because of their larger size, closeness to larger urban centers, or lower growth rate.

Due to limited observations and highly selective variables no attempt has been made to draw any firm generalization pertaining to policy formulation from this study other than focusing on the greater need for comparative and systematic urban ecological research. What is necessary, therefore, is the construction of an urban profile composed of physical, social, economic, and demographic data on every urban center on a national basis. ${ }^{13}$ Preceeding the actual data-gathering, a team of researchers and social scientists should decide on the nature and method of data collection, ${ }^{14}$ focusing not only on the existing resources and conditions but also the potentials thereof, possibly creating a national urban resource data bank. The colossal nature of this task granted, considering the tremendous work involved in the process of collecting and reporting information and data by the Census Bureau this seems quite feasible. This would enable the planners and researchers to view the urban environments in their entirety that might lead to new principles and guidelines regarding effective planning and policy formulation, be it decentralization of industries from existing larger cities, or inducement of industrialization in smaller towns and rural centers from ecological perspectives.

\section{ACKNOWLEDGMENT}

The study was supported in part by a faculty research grant from the Bureau for Faculty Research, Western Washington State College for which the author wishes to thank the Bureau. Thanks are also due to Mr. Eugene Hoerauf, Cartographer of the Department of Geography, for his assistance in processing the data for the project and to Dr. James Scott, Associate Professor, for his many helpful comments in an earlier draft of the paper.

\section{FOOTNOTES}

1The 1971 census reports that 52.41 percent of the total urban population of India resides in cities of
the population size of 100,000 and above. It states further that "At each of the last two censuses, i.e., 1951 
and 1961, it is the cities or the class I towns/town groups which accounted for the largest proportion of urban population. But this has crossed the 50 percent mark only at the 1971 Census." For details see: Census of India 1971 (1971: 8-15).

2For an account of industrial decentralization in India, see Irvin Roth (1970:383-396).

3For an excellent presentation of the "Debate on Urban Policy," see Brian J. L. Berry (1971:140-143); also Sachin Chaudhuri (1962:213-239, particularly pp. 226-239).

4For viewpoints and ideas, see for example, Britton Harris (1962:261-276); Lloyd Rodwin (1970-4-8).

5See for example, D. D. Basu (1965:29-30); M. S. Thacker (1966:39-44).

6See for example, Qazi Ahmad (1965); Brian J. L. Berry and Howard Spodek (1971:266-285); Brian J. L. Berry and Philip H. Rees (1969:445-491).

7From the standpoint of urbanization policy and planning, few would deny the importance of land use as a factor to be studied. For some insights into India's urban land policy and planning see Girijapati Mukharii (1968:582-595); C. S. Chandraskhara (1968:652-669); B. N. Sinha (1965:131-143); Gerald Breese (1963:253-265).

$8 \mathrm{~A}$ few cities were found to be common in the above groups.

${ }^{9}$ This program follows that given in the Sample Program Descriptions in IBM's "System/360 Scientific Subroutine Package."

10For a discussion of this "transformation technique," see Jack E. Vincent (1971:23-27).

11 For the interpretation of relevant variables in the components, only the factor loadings \pm 50 have been extracted.

12In view of economy of space, factor scores are not presented; interested readers may obtain copies by writing to the author.

${ }^{13}$ The Town and Country Planning Organization is to be commended for recognizing this need and making significant contributions toward land use studies of selected cities and towns. See, TCPO (1968: 145-191).

14For an account of a team approach by the potential 'data users' toward data collection preparatory to the 1971 census, see, Census of India 1971 (1971:39).

\section{REFERENCES}

Ahmad, Q. (1965) Indian Cities: Characteristics and Correlates. University of Chicago, Department of Geography, Research Paper 102.

Basu, D. D. (1965) "Industrialization as a Factor Influencing Urban and Regional Development," Journal of the Institute of Town Planners. Nos, 42 and 43 (March-June):24-30.

Berry, B. J. L. (1971) "City Size and Economic Development," pp. 140-143 in Leo Jakokson and Ved Prakash (eds.) Urbanization and National Development. Beverly Hills: Sage Publications.

Berry, B. J. L. and H. Spodek (1971) "Comparative Ecologies of Large Indian Cities," Economic Geography 47 (June):266-285.

Berry, B. J. L. and P. H. Rees (1969) "The Factorial Ecology of Calcutta," The American Journal of Sociology 74 (March): 445-491.

Breese, G. (1963) "Urban Development Problems in India," Annals of the Association of American Geographers 53 (September):253-365.

Census of India, 1971 (1971) "Paper 1 of 1971 - Supplement, Provisional Population Totals." Delhi: Office of the Registrar General and Census Commissioner.

Census of India, 1961 (1970) Vol. 1, Part IX, Census Atlas, Maps 54 and 55. Delhi: Office of the Registrar General and Census Commissioner.

Census of India, 1961 (1962) "Paper 1 of 1962." Delhi: Office of the Registrar General and Census Commissioner.

Chandrasekhara, C. S. (1968) "Land Use and Zoning," The Indian Journal of Public Administration 14 (July-September):652-669.

Chandrasekhara, C. S., et al. (1971) "Growth Changes in India's Urban Population," Proceedings of Symposium on Population Geography, 21 International Geographical Congress, India, 1968. Calcutta, 1971.

Chaudhuri, S. (1962) "Centralization and the Alternate Forms of Decentralization: A Key Issue," pp. 213-239 in Roy Turner (ed.) India’s Urban Future. Berkeley and Los Angeles: University of California Press.

Government of India, Planning Commission (1970) "Regional and Urban Development," Fourth Five Year Plan, 1969-1974. Delhi: Government of India Press.

Harris, B. (1962) "Urban Centralization and Planned Development," pp. 261-276 in Roy Turner (ed.) India's Urban Future. Berkeley and Los Angeles: University of California Press.

Manickam, T. J. and B. Misra (1968) "Urban and Regional Planning." The Indian Journal of Public Administration. 14 (July-September):596-605. 
Mukharii, G. (1968) "Urban Land Policy," The Indian Journal of Public Administration 14 (July-September) :582-595.

Rodwin, L. (1970) Nations and Cities. Boston: Houghton Mifflin Company.

Roth, I. (1970) "Industrial Location and Indian Government Policy," Asian Survey 10 (May):383-396.

Sinha, B. N. (1965) "Urban Land Policy in India," The National Geographical Journal of India 11 (September-December): 131-143.

Thacker, M. S. (1966) “India's Urban Problems," Khadigramodyog 13 (October):39-44.

Town and Country Planning Organization (1968) "Land Use Pattern of India's Cities and Towns," Urban and Rural Planning Thought 11 (October):145-191.

Vincent, J. E. (1971) Factor Analysis in Internationab Relations. Gainesville: University of Florida Press. 
REMAINING COMPONENTS: CITIES AND TOWNS CLASSIFIED

ACCORDING TO SIZE, GROWTH RATE AND LOCATION

100,000 and over

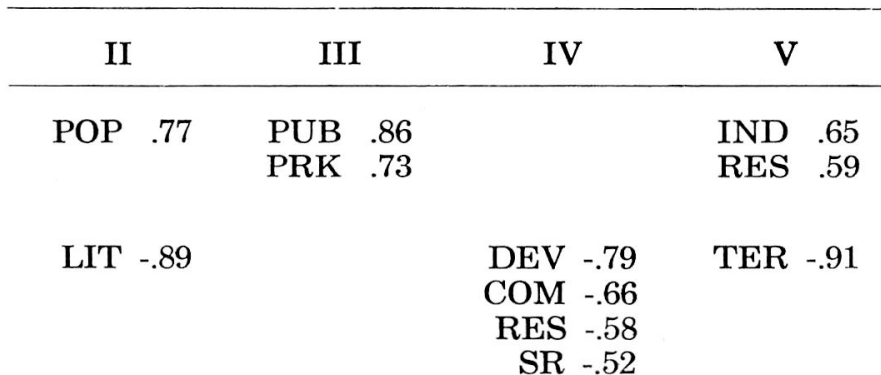

Percent Variance

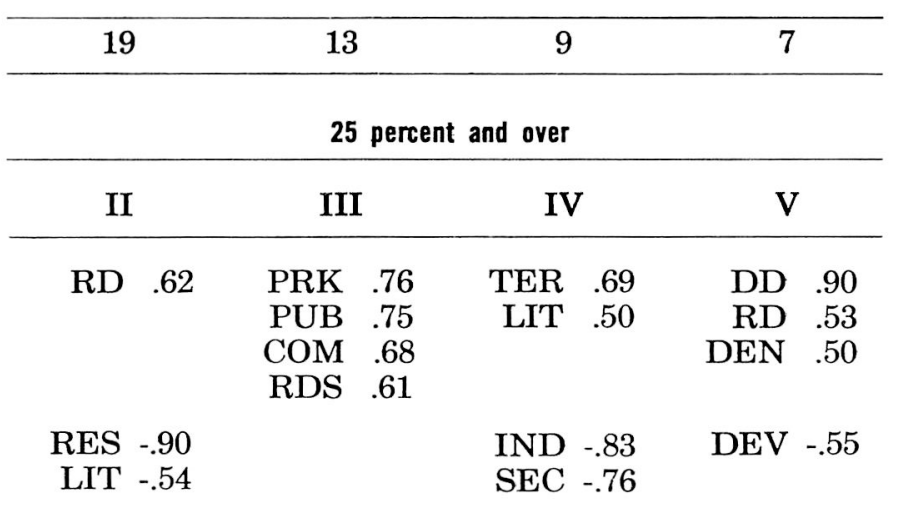

Percent Variance

17

15

11

7
19

13

8

6

$50,000-100,000$

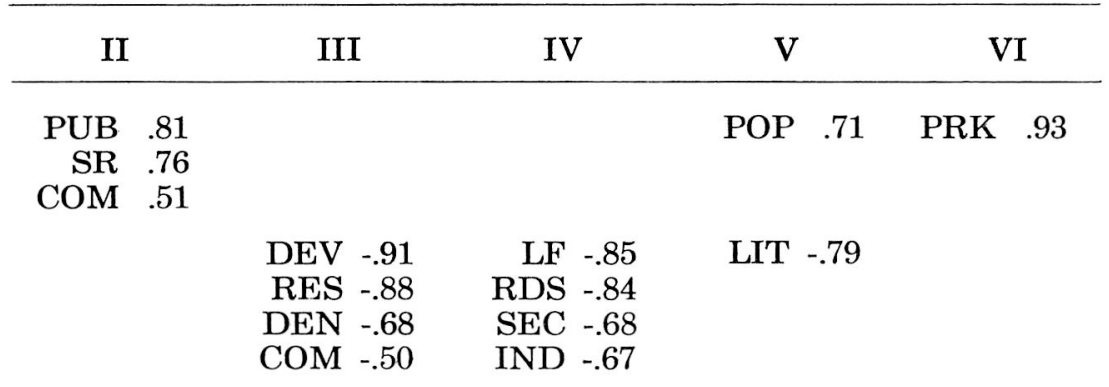

\begin{tabular}{lllll}
\hline 17 & 14 & 11 & 9 & 6
\end{tabular}

Below 25 percent

\begin{tabular}{|c|c|c|c|c|c|c|c|}
\hline \multicolumn{2}{|c|}{ II } & \multicolumn{2}{|c|}{ III } & \multicolumn{2}{|c|}{ IV } & \multicolumn{2}{|c|}{$\mathbf{V}$} \\
\hline RES & .94 & LIT & .84 & POP & .79 & $\mathbf{L F}$ & .51 \\
\hline \multirow{3}{*}{\multicolumn{2}{|c|}{ DEV .89}} & PUB & .74 & COM & .62 & & \\
\hline & & PRK & .61 & & & & \\
\hline & & COM & .51 & & & & \\
\hline $\mathrm{RD}$ & -.59 & & & & & SR & -.89 \\
\hline 19 & & 13 & & 8 & & 6 & \\
\hline
\end{tabular}


Over 40 miles

40 miles and below

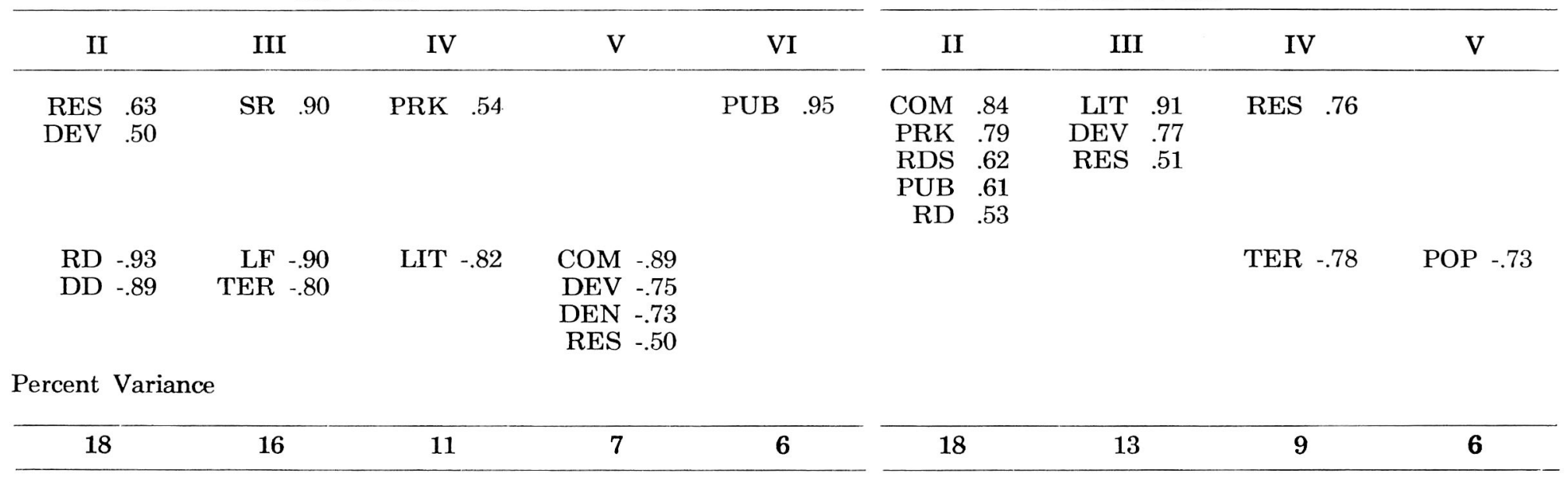

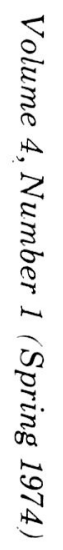

